\title{
Mode I Fracture Energy of Adhesive Joints Bonded with Adhesives with Different Characteristics Under Quasi-static and Impact Loading
}

\author{
Yu SEKIGUCHI*, Yuki YAMAGATA**, Chiaki SATO*
}

\begin{abstract}
Double cantilever beam joints were manufactured from spring steel substrates bonded together using a twopart epoxy adhesive, a two-component type second-generation acrylic adhesive, and a one-part polyurethane adhesive. Rheological behavior of the adhesives was measured with a dynamic mechanical analyzer. Mode I fracture behavior of the joints was investigated with a tensile test machine and a falling-wedge impact test machine changing opening speeds from $8.33 \times 10^{-5} \mathrm{~m} / \mathrm{s}$ to about $1.9 \mathrm{~m} / \mathrm{s}$. Although stable fracture was observed for the epoxy and polyurethane adhesives under the tested conditions, unstable (i.e. stick-slip) fracture was observed for the acrylic adhesive when increasing the opening speed. Adhesive fracture energy, $G_{\mathrm{IC}}$, was estimated using several methods. Different dynamic dependency of the fracture energy was observed depending on the type of adhesive, and correlation between the change of fracture energy against opening speed and the change of dynamic loss tangent against temperature was suggested.
\end{abstract}

Key words : Adhesive fracture energy, Impact DCB test, Dynamic fracture

\section{Introduction}

Recently, adhesive bonding has been widely used in industry. Along with dramatic expansion of the demand for adhesive bonding, the types of adhesives and the applications continue to increase. Especially for structural adhesive bonding in the industrial use, such as cars, buses, and other vehicles, safety of the bonded parts is important and accurate evaluation of the strength of adhesive joints is essential. Adhesive fracture energy is one of the important parameters for fracture analyses of the adhesive joints. Evaluation methods of mode I fracture energy has been widely studied and standardized for the composites ${ }^{1 \sim 4)}$, and it has been applied for the adhesively bonded specimens, such as double

\footnotetext{
* Institute of Innovative Research, Tokyo Institute of Technology, 4259 Nagatsuta-cho, Midori-ku, Yokohama 226-8503, Japan

** Interdisciplinary Graduate School of Science and Engineering, Tokyo Institute of Technology,

4259 Nagatsuta-cho, Midori-ku, Yokohama 226-8503, Japan

(Received : May 9, 2017)
}

cantilever beam (DCB) and tapered double cantilever beam (TDCB) specimens, under quasi-static condition ${ }^{5 \sim 10)}$. Dynamic fracture test methods using the DCB and TDCB specimens are also investigated with a servo-hydraulic testing machine and a falling-wedge impact test machine ${ }^{11 \sim 16)}$. Due to the development of various high toughness adhesives, there is a growing demand to evaluate speed dependencies of adhesive toughness. Because the speed dependencies of the plastic materials are highly related to rheological characteristics, three adhesives with different material properties are selected and dynamic effect on the fracture energy is investigated associating with rheological behavior of the adhesives.

\section{Experimental}

\subsection{Material and Specimen}

Spring streel (SUP10) with the length $l=188.0 \mathrm{~mm}$, width $b=24.8 \mathrm{~mm}$, thickness $h=2.0 \mathrm{~mm}$ was used for substrates of double cantilever beam (DCB) test specimens. The material with high yield stress was selected to avoid plastic deformation of the substrates. Three adhesives with 
different material properties were used in the experiment. One is an epoxy ('EP') adhesive (DENATITE 2204, Nagase Chemtex Corp., Osaka, Japan, curing condition: $100{ }^{\circ} \mathrm{C}$ for $30 \mathrm{~min}$ ). Another is a second-generation acrylic ('SGA') adhesive (HARDLOC C355-20, Denka Co. Ltd., Tokyo, Japan, curing condition: $60{ }^{\circ} \mathrm{C}$ for 24 hours). The other is a singlecomponent polyurethane ('PU') adhesive (Penguin Seal, Sunstar Engineering Inc., Osaka, Japan, curing condition: 25 ${ }^{\circ} \mathrm{C}$ for 7 days). For the PU adhesive, prototype primer (Sunstar Engineering Inc., Osaka, Japan) was used. Each surface was sandblasted with $\mathrm{Al}_{2} \mathrm{O}_{3}$ abrasive grain and then cleaned with acetone prior to bonding. Adhesive layer was set inserting a polytetrafluoroethylene (PTFE) film with a thickness of $0.1 \mathrm{~mm}$ into both ends of the substrates to control the layer thickness as well as create an initial crack.

\subsection{Dynamic Mechanical Analysis}

Material properties were measured with a dynamic mechanical analyzer (DMS7100, Hitachi High-Technologies Corp., Tokyo, Japan). Specimens with the width $5 \mathrm{~mm}$, and the thickness $1 \mathrm{~mm}$ were manufactured and accurate size after curing was measured before each test. Frequency and heating rate were set to $1 \mathrm{~Hz}$, and $2{ }^{\circ} \mathrm{C} / \mathrm{min}$, and temperature was changed for wide range.

\subsection{Double Cantilever Beam test}

The fracture test of the DCB specimens were conducted three times for each condition with a tensile test machine (STB-1225S, A\&D Co. Ltd., Tokyo, Japan) for the opening speed of $5 \mathrm{~mm} / \mathrm{min}$ and $500 \mathrm{~mm} / \mathrm{min}$, and a falling-wedge impact test machine (see Fig. 1) for the fastest opening speed. The fracture process during the test was recorded

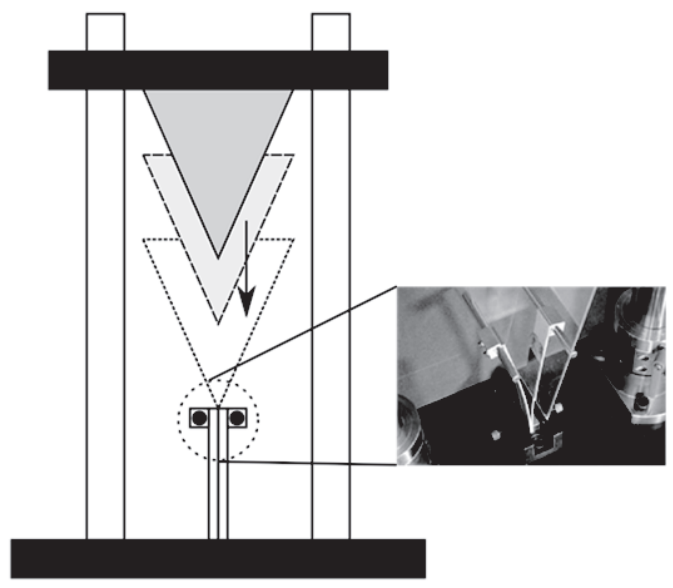

Fig. 1 Falling wedge impact test configuration with a camera, and the opening displacement and the crack length were manually measured from the obtained pictures for each test. The resolution of the pictures was higher than $0.2 \mathrm{~mm}$ per pixel. The load was also measured for the tests with the tensile test machine. The room temperature was set to be $24{ }^{\circ} \mathrm{C}$ during the tests.

\section{Results and Discussion}

\subsection{DMA results}

Glass transition temperature, Tg, was obtained from the peak of the dynamic loss tangent, $\tan \delta$, as $115.4{ }^{\circ} \mathrm{C}$ for the EP, $86.7{ }^{\circ} \mathrm{C}$ for the SGA, and $-47.4{ }^{\circ} \mathrm{C}$ for the PU adhesives, respectively. Storage modulus at $24{ }^{\circ} \mathrm{C}$ was $5.97 \mathrm{GPa}$ for the $\mathrm{EP}, 1.11 \mathrm{GPa}$ for the SGA, and 44.9 MPa for the PU adhesives, respectively. The change in $\tan \delta$ with temperature is shown in Fig. 2. It is obvious that the EP and SGA adhesives are in a glass state and the PU adhesive is in a rubber state at the room temperature condition. From the change of $\tan \delta$ when the temperature decreases, the change of the material behavior is expected to be larger for the SGA and $\mathrm{PU}$ adhesives than that for the EP adhesive.

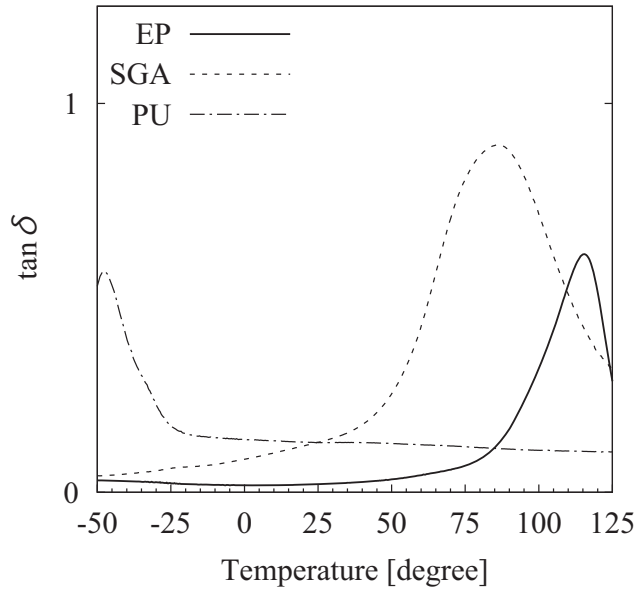

Fig. 2 DMA results of the relation between dynamic loss tangent and temperature.

\subsection{DCB results}

The opening speed with the impact test machine was calculated from the measured displacement as $1.88 \mathrm{~m} / \mathrm{s}$ for the $\mathrm{EP}, 1.89 \mathrm{~m} / \mathrm{s}$ for the SGA, and $1.87 \mathrm{~m} / \mathrm{s}$ for the PU adhesives, respectively. For convenience, we denoted the tests with the tensile test machine for $5 \mathrm{~mm} / \mathrm{min}$ as slow speed ('SS') tests, that for $500 \mathrm{~mm} / \mathrm{min}$ as middle speed ('MS') tests, and the tests with the impact test machine as fast speed ('FS') tests. Crack propagation for each test is shown in Fig. 3 for the EP, Fig. 4 for the SGA, and Fig. 5 for the PU 
adhesives. It has been reported that the fracture type of the DCB test changes from stable to unstable, i.e. from continuous fracture to stick-slip fracture, and then back to stable propagation with increasing the opening speed in the case for rubber-toughened single-part epoxy adhesives ${ }^{14,15)}$. For the tested condition presented here, only the stable fracture was observed for the EP and PU adhesives, whereas the crack propagation became wavier for faster testing speed. In contrast, the fracture type was changed from stable to unstable at between the SS and MS tests for the SGA adhesive, as shown in Fig. 4. Although failure type was cohesive for all tested speeds, whitening was observed for the whole part in the SS test and the stuck part in the MS test for the SGA adhesive. The whitening parts on the surface of the MS test is related to the load peak points in Fig. $4 \mathrm{~b}$, and striped pattern due to the stick-slip behavior was recorded on the fracture surface, as shown in Fig. 6.

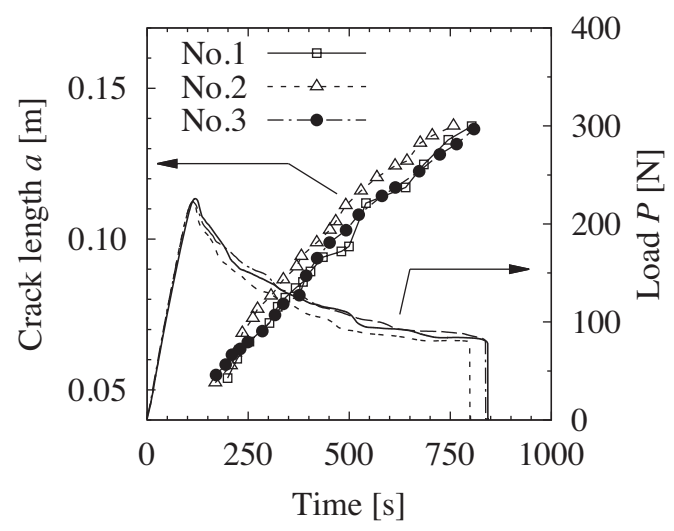

(a) SS

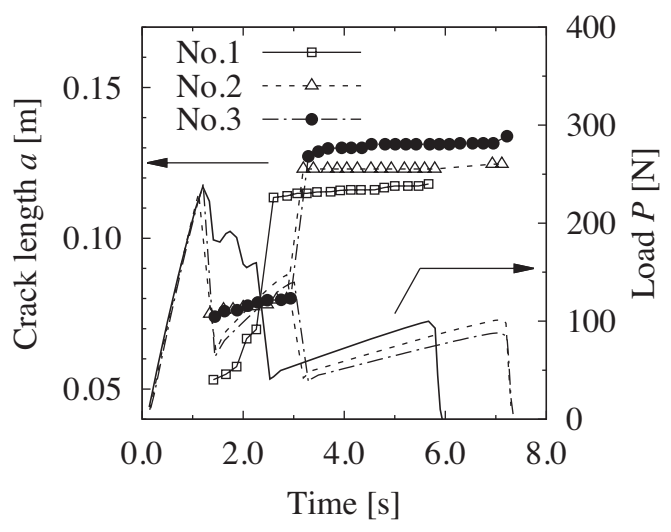

(b) MS

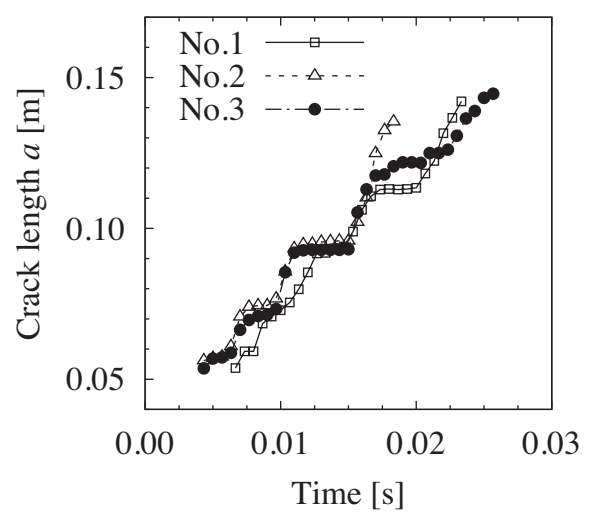

(c) FS

Fig. 4 The relation between crack length (or load) and time for the second-generation acrylic adhesive (a) slow speed (5 $\mathrm{mm} / \mathrm{min}$ ), (b) middle speed (500 $\mathrm{mm} / \mathrm{min})$, and (c) fast speed tests $(1.89 \mathrm{~m} / \mathrm{s})$. 


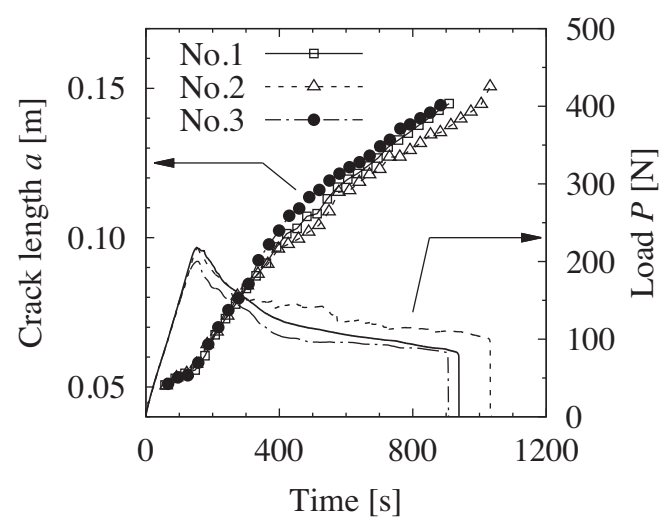

(a) SS

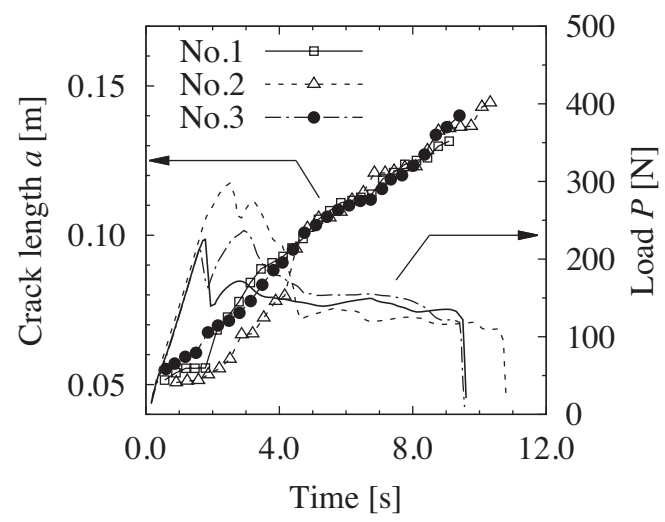

(b) MS

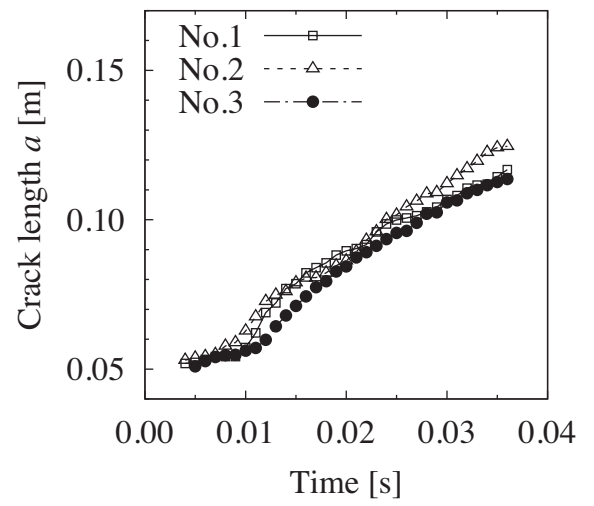

(c) FS

Fig. 5 The relation between crack length (or load) and time for the polyurethane adhesive (a) slow speed $(5 \mathrm{~mm} / \mathrm{min})$, (b) middle speed $(500 \mathrm{~mm} / \mathrm{min})$, and (c) fast speed tests $(1.87$ $\mathrm{m} / \mathrm{s})$.

\subsection{Fracture energy calculation}

The adhesive fracture energy, $G_{\mathrm{IC}}$, has been widely studied and standardized at slow, quasi-static loading rates using a fracture mechanics approach. It is determined based on liner elastic fracture mechanics by

$$
G_{\mathrm{IC}}=\frac{P^{2}}{2 b} \frac{\mathrm{d} C}{\mathrm{~d} a},
$$

where $P$ is the applied load, $b$ is the specimen width, $C$ is the compliance, which is given by $G_{\mathrm{IC}}, \delta$ is the opening displacement, and $a$ is the crack length. Using the simple beam

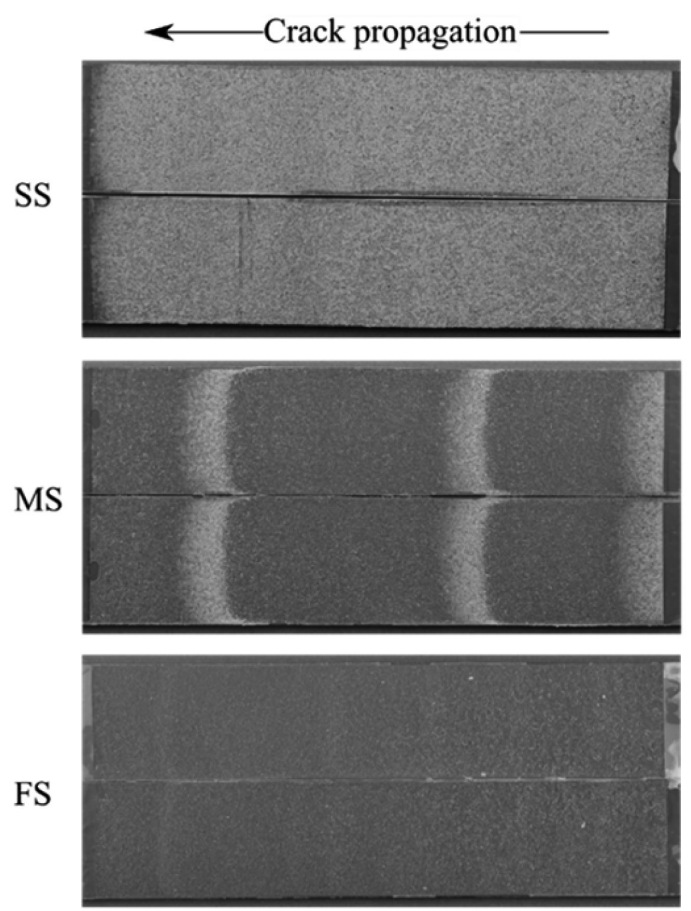

Fig. 6 Fracture surfaces of the DCB specimens bonded with the SGA adhesive.

theory (SBT), $\mathrm{d} C / \mathrm{d} a$ is given by

$$
\frac{d C}{d a}=\frac{2 a^{2}}{E I}
$$

where $E$ is the modulus of the substrate and $I$ is the moment of inertia of the cross section, $I=b h^{3} / 12$, where $h$ is the height of the substrate. Therefore, the measurement of the load, the opening displacement, and the crack length is required to determine the value of $G_{\mathrm{IC}}$. Additionally, some correction should be applied for the accurate $G_{\mathrm{IC}}$ calculation because of the deviation from the SBT. One of the corrected methods is the corrected beam theory (CBT), which uses a crack length correction, $|\Delta|^{4,6,9)}$. The fracture energy with the CBT is given by

$$
G_{\mathrm{IC}}=\frac{3 P \delta F}{2 b(a+|\Delta|)} .
$$

The displacement correction factor, $F$, is derived as ${ }^{17)}$

$$
F=1-0.3\left(\frac{\delta}{a}\right)^{2}-1.5\left(\frac{l_{1} \delta}{a^{2}}\right)
$$

The crack length correction is obtained by plotting $C^{1 / 3}$ versus the measured crack length. The results of $|\Delta|$ for the SS and MS tests are listed in Table 1.

In order to reduce crack length measurement, which is difficult and time- ${ }^{-}$consuming tasks, compliance-based beam method (CBBM) has been investigated ${ }^{9,18)}$. With this method, the crack length is calculated from the measured load and displacement as 
Table 1 Calculated values of the crack length corrections.

\begin{tabular}{c|c|c|c|c|c|c|c}
\hline \multicolumn{2}{c|}{} & \multicolumn{2}{c|}{$\mathrm{EP}$} & \multicolumn{2}{c|}{ SGA } & \multicolumn{2}{c}{ PU } \\
\cline { 3 - 8 } \multicolumn{2}{c|}{} & $|\Delta|$ & $\Delta_{\text {СвBM }}$ & $|\Delta|$ & $\Delta_{\text {СвBM }}$ & $|\Delta|$ & $\Delta_{\text {СвBM }}$ \\
\hline \multirow{3}{*}{ SS } & No.1 & 0.0160 & 0.0181 & 0.0198 & 0.0227 & 0.0014 & 0.0146 \\
\cline { 2 - 8 } & No.2 & 0.0173 & 0.0203 & 0.0161 & .0193 & 0.0026 & 0.0118 \\
\cline { 2 - 8 } & No.3 & 0.0124 & 0.0183 & 0.0157 & 0.0214 & 0.0044 & 0.0152 \\
\hline \multirow{3}{*}{ MS } & No.1 & 0.0168 & 0.0153 & & 0.0171 & 0.0161 & 0.0116 \\
\cline { 2 - 8 } & No.2 & 0.0131 & 0.0199 & & 0.0165 & 0.0100 & 0.0142 \\
\cline { 2 - 8 } & No.3 & 0.0128 & 0.0154 & & 0.0176 & 0.0039 & 0.0087 \\
\hline \multicolumn{2}{c}{ Average } & 0.0147 & 0.0179 & 0.0172 & 0.0191 & 0.0064 & 0.0127 \\
\hline
\end{tabular}

$$
\begin{aligned}
& a_{C B B M}=\left(\sqrt{q_{1}^{2}+p_{1}^{3}}-q_{1}\right)^{\frac{1}{3}}-\left(\sqrt{q_{1}^{2}+p_{1}^{3}}+q_{1}\right)^{\frac{1}{3}}, \\
& p_{1}=h^{2} / 3
\end{aligned}
$$

and

$$
q_{1}=-E b h^{3} \delta / 16 P .
$$

The fracture energy with the CBBM is then given by

$$
G_{\mathrm{IC}}=\frac{4 P^{2} F}{E b^{2} h^{3}}\left(3 a_{\mathrm{CBBM}}^{2}+h^{2}\right) .
$$

Another advantage of the CBBM is related to the fact that the calculated crack length includes the effect of the fracture process zone ${ }^{8)}$. Therefore, the gap between the calculated and measured crack lengths, $\Delta_{\mathrm{CBBM}}=a_{\mathrm{CBBM}}-a$, can be another correction factor for the crack length. The results of $\Delta_{\text {Сввм }}$ for the SS and MS tests are listed in Table 1.

For the dynamic fracture tests with the impact test machine, the load cannot be measured. Therefore, load reduction scheme is required to calculate the fracture energy. Because the relation among the load, the displacement, and the crack length is determined by the beam theory, load independent method (LIM) to calculate the fracture energy has been investigated ${ }^{11,19)}$. Although crack length correction is essential for the accurate calculation of the fracture energy using the LIM, the correction cannot be determined without measuring the load. Although the correction contains many effects and some may have dynamic dependency, an average value of the correction obtained from the results of the SS and/or MS tests is used for the calculation of the fracture energy overall. We denote the fracture energy calculated with the LIM using the crack length correction, $|\Delta|$, as $\mathrm{LIM}_{\Delta}$ and that using the CBBM crack length correction, $\Delta_{\text {СвBM }}$, as LIM $_{\text {СвBM. }}$. The fracture energy is given by

$$
G_{\mathrm{IC}}=\frac{9 \delta^{2} E I F}{4 b(a+|\Delta|)^{4}}
$$

for $\mathrm{LIM}_{\Delta}$ and

$$
G_{\mathrm{IC}}=\frac{9 \delta^{2} E I F}{4 b\left(a+\Delta_{\mathrm{CBBM}}\right)^{4}}
$$

for LIM $_{\text {CBBM. }}$. Because the kinetic energy of the substrate ${ }^{20)}$ is small enough compared to the fracture energy for the tested conditions, the dynamic effect on the fracture energy is neglected.

The results of the fracture energy with the CBT, CBBM, $\operatorname{LIM}_{\Delta}, \mathrm{LIM}_{\text {CBBM }}$ for the SS and MS tests, and that with the $\mathrm{LIM}_{\Delta}$ and LIM ${ }_{\text {CBBM }}$ for the FS test are shown in Fig. 7. Tendency of the $\mathrm{LIM}_{\Delta}$ to become slightly larger from the other methods overall, especially for the PU adhesive, is due to the small value of the crack length correction. Even with this in mind, it is obvious that the fracture energy with the LIMs well correspond to the other methods. In contrast, the effect of the opening speed on the fracture energy is different with the adhesive types. Fracture energy normalized by the fracture energy of the SS test for each case, i.e., fracture energy change ratio from the SS test, is shown in Fig. 8. For the EP adhesive, the fracture energy changed little with the opening speed. For the SGA adhesive, the change was small at between the SS and MS tests, but dramatically decreased at the FS test. Although the stick-slip fracture was occurred both for the MS and FS tests, whitening was only observed for the MS test. Therefore, it is predicted that the disappearance of the whitening contributes to the decrease of the fracture energy. For the PU adhesive, it constantly increased from the SS to the FS tests.

The change of the fracture energy with the opening speed can also be confirmed from the relation between the crack length and the opening displacement. The crack propagates more when the fracture energy decreases. Conversely, it propagates less with increasing the fracture energy. The comparison of the relation for the SS and FS tests is shown in Fig. 9. Little change in the fracture energy is predicted for the EP adhesive because all the results followed the same relation between the crack length and the displace- 


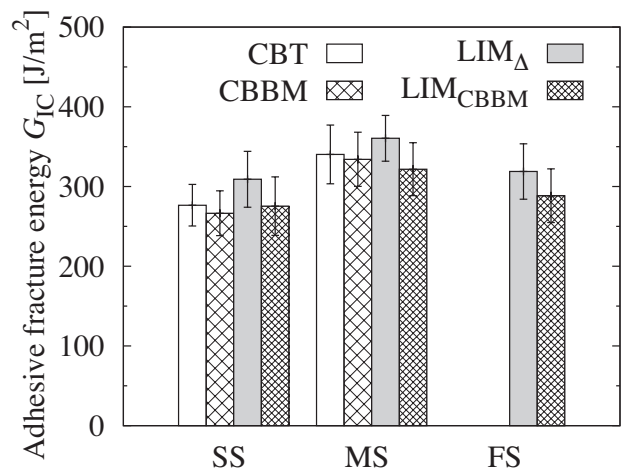

(a) EP

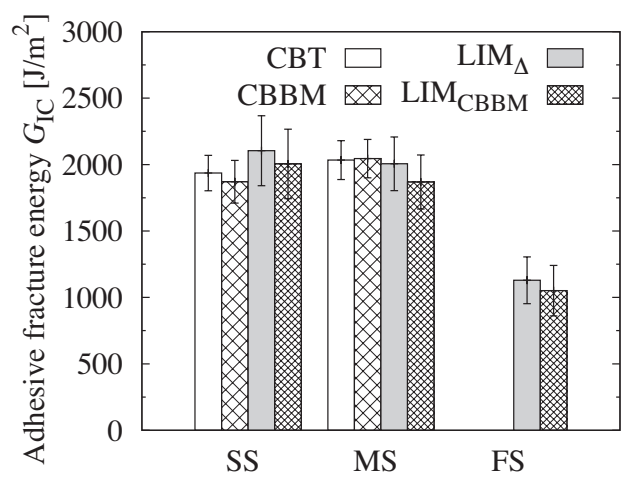

(b) SGA

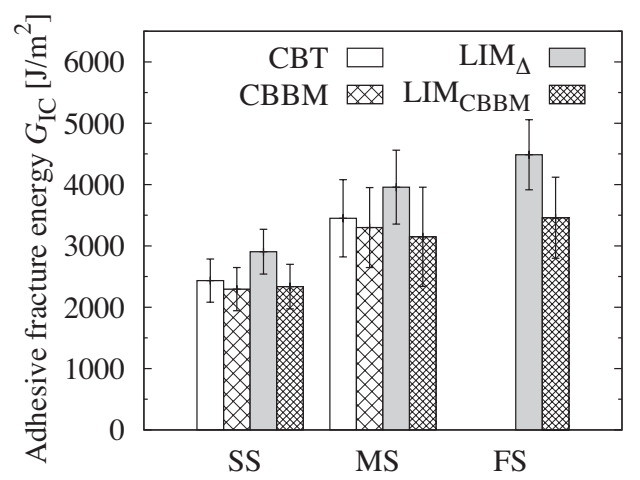

(c) PU

Fig. 7 Adhesive fracture energy results for (a) the epoxy, (b) the second-generation acrylic, and (c) the polyurethane adhesives.

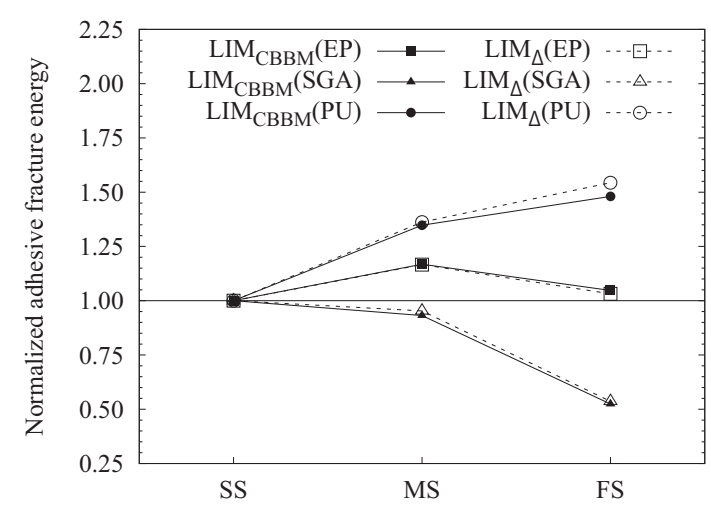

Fig. 8 Change of adhesive fracture energy with the testing speed normalized by the results of the slow speed (SS) test.

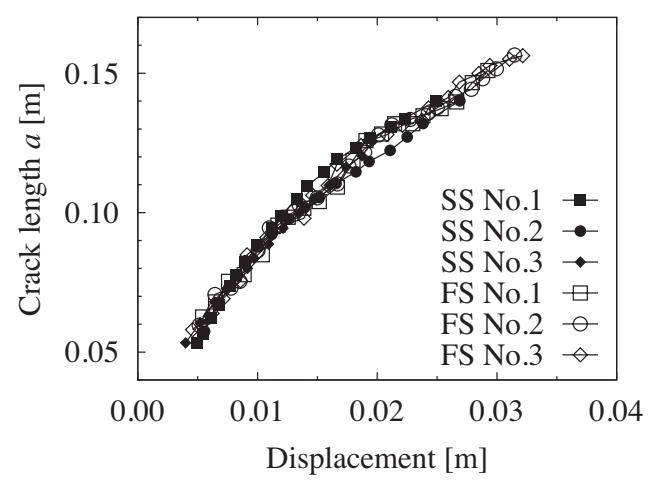

(a) EP

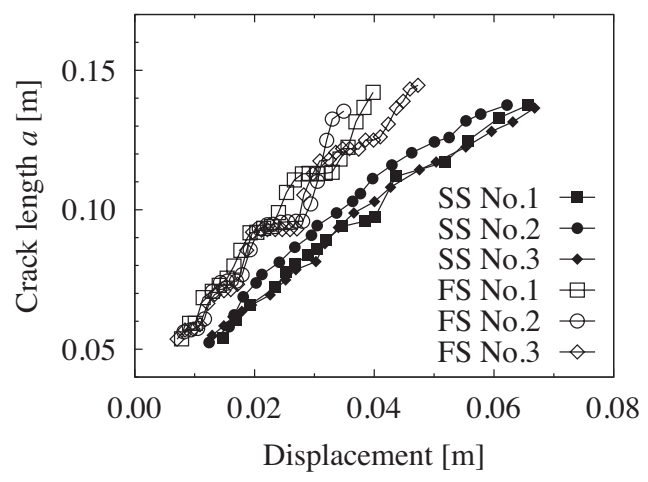

(b) SGA

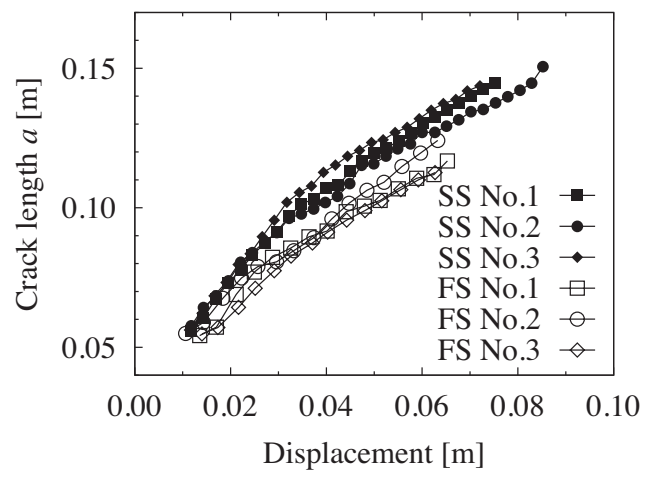

(c) PU

Fig. 9 Crack propagation against the displacement for (a) the epoxy, (b) the second-generation acrylic, and (c) the polyurethane adhesives.

ment. The results of the FS test were above the results of the SS test for the SGA adhesive. Therefore, the crack propagated more at the same displacement for the FS test and the decrease of $G_{\mathrm{IC}}$ with increasing the opening speed is obvious. Opposite can be said to the results for the PU adhesive.

Due to the time temperature dependence of linear viscoelastic behavior of the polymers, adhesive behavior with dynamic deformation at the room temperature relates to the behavior with quasi-static deformation at lower temperature. Thus, the change of the fracture energy with increasing the opening speed shown in Fig. 8 corresponds to the 
change of $\tan \delta$ with decreasing the temperature shown in

Fig. 2. With decreasing the temperature, $\tan \delta$ kept almost constant for the EP, decreased for the SGA, and increased for the PU adhesives. The changes of $\tan \delta$ with decreasing the temperature well corresponds to the change of the fracture energy with increasing the opening speed. Although there may exist many other factors to be considered, it is interesting that the fracture energy change is related to the rheological behavior of the adhesives.

\section{Conclusion}

Dynamic effect on the adhesive fracture energy is investigated using the adhesives with different material behaviors. Because of the difference of the glass transition temperature among the tested adhesives, the dynamic loss tangent against the temperature was different each other, especially in the range lower than room temperature, which is important for the dynamic deformation. The fracture energies of the adhesives were measured using the DCB specimens changing the opening speed. The correlation between the dynamic dependency of the adhesive fracture energy and the rheological behavior of the materials was observed.

\section{Acknowledgements}

This paper is based on the results from a future pioneering program commissioned by the New Energy and Industrial Technology Development Organization (NEDO). The authors would like to express their sincere appreciation to the project members who have provided valuable information and participated in useful discussions. We also wish to thank Sunstar Engineering Inc. (Japan) for the material supply and Denka Co. Ltd. (Japan) for kind cooperation for the DMA experiments.

\section{References}

1) M. F. Kanninen, Int. J. Fract., 9 , 83 (1973).

2) J. G. Williams, Int. J. Fract., 36, 101 (1988).

3) JIS K7086 (1993).

4) ASTM D5528-13 (2913).

5) B. Blackman, et al., J. Mater. Sci. Lett., 10, 253 (1991).

6) B. R. K. Blackman, et al., Int. J. Adhesion Adhesives, 23, 293 (2003).

7) F. J. P. Chaves, et al., J. Adhesion, 90, 955 (2014).

8) M. D. Banes, L. F. M. da Silva and R. D. S. G. Campilho, J. Adhesion, 91, 331 (2015).

9) Y. Sekiguchi, M. Katano and C. Sato, J. Adhesion, 93, 235 (2017).

10) ASTM D3433-99 (2012).

11) B. R. K. Blackman, et al., J. Mater. Sci., 30, 5885 (1995).

12) S. Xu and D. A. Dillard, IEEE Trans. Comp. Packaging Technol., 26, 554 (2003).

13) J. C. Simon, E. Johnson and D. A. Dillard, J. ASTM Int., 2, JAI12955 (2005).

14) B. R. K. Bkackman, et al., Eng. Fract. Mech., 76, 2858 (2009).

15) A. Karac, et al., Eng. Fract. Mech., 78, 973 (2011).

16) B. R. K. Blackman, A. J. Kinloch, F. S. Rodriguez-Sanchez and W. S. Teo, Int. J. Solids Struct., 49, 1434 (2012).

17) J. G. Williams, J. Strain Analysis, 24, 207 (1989).

18) M. F. S. F. de Moura, J. J. L. Morais and N. Dourado, Eng. Fract. Mech., 75, 3852 (2008)

19) Y. Yamagata, X. Lu, Y. Sekiguchi and C. Sato, Appl. Adhes. Sci., 5(7) (2017).

20) B. R. K. Blackman, A. J. Kinloch, Y. Wang and J. G. Williams, J. Mater. Sci., 31, 4451 (1996). 


\title{
<研究論文 $>$
}

(受理：平成 29 年 5 月 22 日)

\section{特性の異なる接着剂を用いた接着接合部の準静的および 動的負荷下に扮ける破壊エネルギー}

\author{
関口＼cjkstart悠 $*$ ・山形 勇樹 $* * \cdot$ 佐藤 千明 $*$ \\ 要 旨
}

高分子材料である接着剂は, 種々様々な動的粘弾性特性を持っている。接着剂特性の違いによる破壊じん 性の速度依存性変化を調べるため，被着体にばね鋼鋼材，接着剂に 2 液エポキシ系接着剤，第二世代アクリ ル系接着剂，1 液ポリウレタン系接着剤を用いて双片持ちはり（DCB）試験片を作成し，モード I 破壊じん性を 測定した。また, 動的粘弾性測定装置を用い接着剤の粘弾性特性を測定した。試験速度を変えて破壊じん性 值を測定することにより，動的粘弾性特性の異なる接着剤では異なる速度依存性を示すことが示された。エ ポキシ・ポリウレタン系接着剤ではいずれの試験速度においても連続的な破壊が観察されたのに対し, アク リル系接着剤では速度の増加に伴い不安定破壊 (Stick-Slip 現象) が観察された。また, 破壊じん性值の速度依 存性と接着剂の動的粘弾性特性に関係性が示唆された。

\footnotetext{
* 東京工業大学 科学技術創成研究院

神奈川県横浜市緑区長津田町 4259 ～226-8503

**東京工業大学 総合理工学研究科

神奈川県横浜市緑区長津田町 4259 ２26-8503

(原稿受付日：平成 29 年 5 月 9 日)
} 